Canadian
JOURNAL
MEDICINE

\title{
Oncogenic Role of Cancer Stem Cell LGR5 in Colorectal Cancer Progression
}

\author{
Sourena Ghorbani Kalkhajeh' ${ }^{\mathbf{1}}$, Alireza Parsanezhad ${ }^{2}$, Mahdieh Banoei ${ }^{3}$, \\ Maryam Vahidi', Maziar Malekzadeh Kebria ${ }^{5}$, Zahra Pezeshkian ${ }^{6}$, Noshad \\ Peyravian $^{7 *}$ \\ ${ }^{1,2}$ Department of Radiologic Technology, School of Allied Medical Sciences, Ahvaz Jundishapur \\ University of Medical Sciences, Ahvaz, Iran \\ ${ }^{3}$ Department of Molecular Medicine, National Institute of Genetic Engineering and Biotechnology, \\ Tehran, Iran \\ ${ }^{4}$ Department of Medical Genetics, National Institute of Genetic Engineering and Biotechnology, \\ Tehran, Iran \\ ${ }^{5,7}$ Cellular and Molecular Research Center, Iran University of Medical Sciences, Tehran, Iran \\ ${ }^{5,7}$ Department of Tissue Engineering and Regenerative Medicine, Faculty of Advanced \\ Technologies in Medicine, Iran University of Medical Sciences, Tehran, Iran \\ ${ }^{6}$ Department of Genetics, Tehran Medical Sciences Branch, Islamic Azad University, Tehran, Iran
}

\begin{abstract}
Keywords:
Cancer stem cell, LGR5,

Adenoma-carcinoma

sequence

\section{Received}

20 November 2021

Received in revised form

01 December 2021

Accepted

01 December 2021

Colorectal Cancer (CRC) is the second most common cancer in women and the third most common cancer in men. There is strong evidence for the role of Cancer Stem Cells (CSCs) in cancer progression. The identification and understanding CSCs genes such as LGR5 involved in the induction of cancer development is crucial in the prognosis of CRC. LGR5 is a membrane protein involved in several molecular signaling pathways, such as the Wnt signaling and NOTCH pathways. It has been shown that the LGR5 gene was overexpressed in CRC and is associated with the worst outcomes in patients with CRC, but molecular mechanisms of LGR5 in CRC development have been poorly identified. This review has summarized current studies about the role of stem cell marker of LGR5 in CRC progression. Future research in this area may improve the early detection of CRC, new therapies, and monitoring of CRC.
\end{abstract}

ABSTRACT

*Correspondence:

peyravian.n@iums.ac.ir 


\section{Introduction}

Cancer Stem Cells (CSCs) are a subpopulation of neoplastic cells with self-renewal potential responsible for cancer progression, metastasis, invasion, and pharmacological resistance. These cells express many cancer stem cell markers, which are used to identify cancer cells. Furthermore, many investigations proved the association of these markers with clinicopathological features in patients who had cancer [1,2].

CRC is introduced as the third most common cancer in males and the second in females; an increasing body of evidence indicates that CRC incidence and mortality rates are rising in the world [3, 4]. Many specific gene alterations, such as Adenomatous Polyposis Coli (APC), KRAS (Kirsten rat sarcoma two viral oncogene homolog), and P53 (Tumor protein p53), result in CRC initiation and progression. $A P C$ acts as a tumor suppressor gene, and its defect interrupts the Wnt signaling pathway; in the following gain-of-function (GOF), mutations of the KRAS and loss of P53 can lead to normal mucosa into cancerous tissue [5-9]. Many cancer stem cell markers are involved in colorectal development [10]. One of the CSCs is Leucine-rich repeat-containing G-protein-coupled receptor 5 (LGR5), a membrane protein involved in many pathways, such as the Wnt signaling and NOTCH pathway [10, 11]. Generally, many studies have demonstrated that the LGR5 gene has an oncogenic role in numerous cancers, such as neuroblastoma, thyroid cancer, glioma, and CRC. As well, LGR5 can improve metastasis, tumor growth, epithelial-mesenchymal transition (EMT), and drug resistance [12-14]. LGR5 protein has been identified as an intestinal marker, i.e., a prooncogene, and a target of Wnt/ $\beta$-catenin signaling pathway. This signaling acts a critical action in cell proliferation, cancerous cell stability, and tumor progression in CRC [15-17]. Wnt receptors are induced by the binding of R-Spondin (RSPO) to LGR5 and joining Wnt ligands; furthermore, induced Wnt signaling can stabilize $\beta$-catenin and stimulate downstream targeted genes, such as $c-M Y C, A X I N 2, C y c l i n D 1$, resulting in transformation of a normal tissue to CRC (Figure 1) [17-19]. It has been indicated that LGR5 gene was meaningfully upregulated in CRC compared with normal mucosa, resulting in worst outcomes in patients with CRC (Figure 2) [19].

Figure 1 indicates that R-spondin stimulates LGR5. Then, LGR5 protein activates the LPR-frizzled receptor complex that joins WNT ligands and increases WNT signaling activation via phosphorylation of LRP5/6. In the following, $\beta$-catenin is translocated to the nucleus, binds to transcription factor LEF/TCF, and enhances the expression of WNT target genes, such as $c-M Y C, L G R 5$, and CyclinD1. Upregulation of these genes leads tumor to cell proliferation, EMT, stemness of CSCs, and tumor progression. 


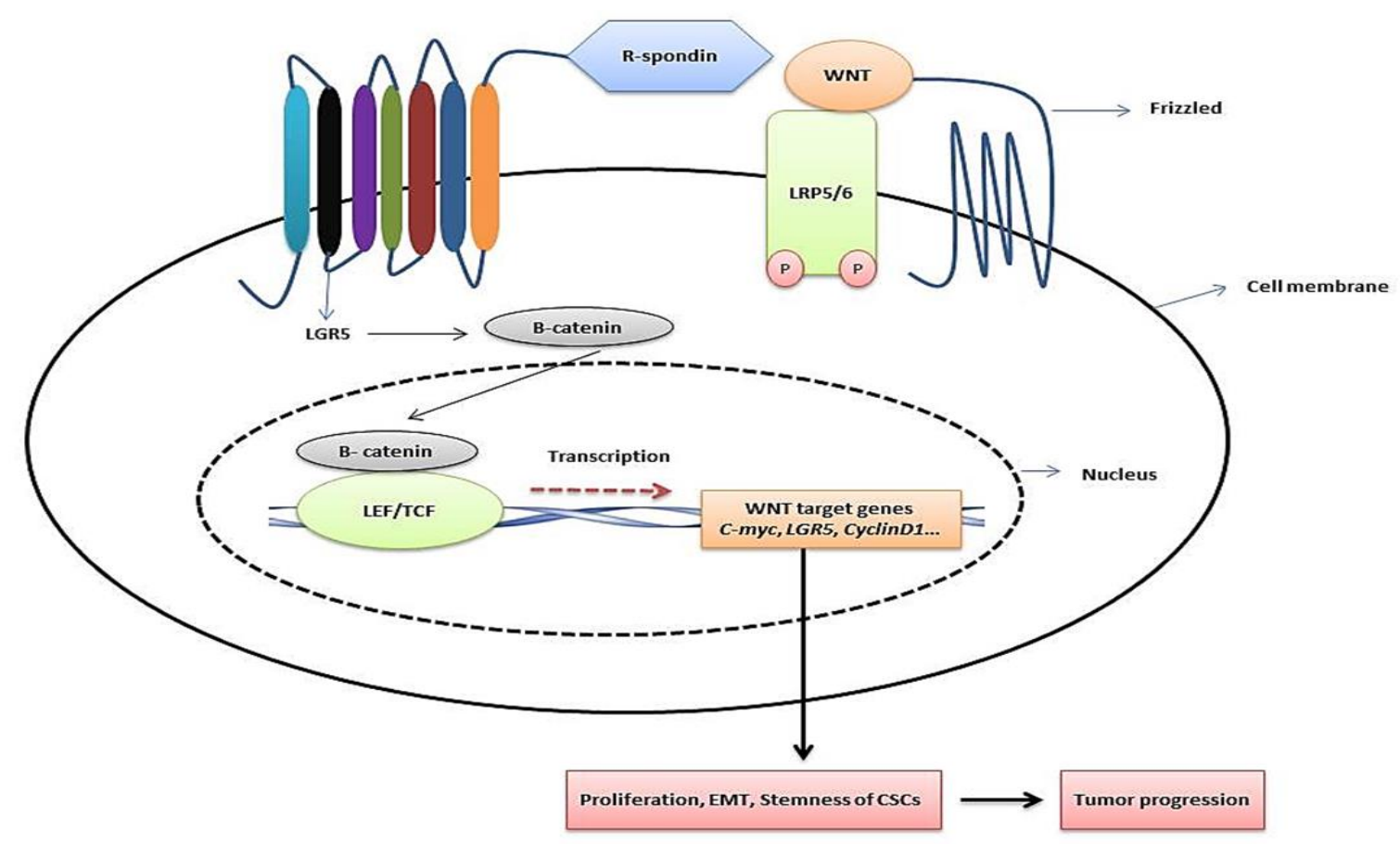

Figure 1. A schematic pattern of the LGR5-mediated activation of colorectal tumor growth through interaction with the WNT/ $\beta$-catenin signaling pathway.

Figure 2 illustrates that overexpression of the LGR5 gene can affect colorectal carcinogenesis and lead normal mucosa to advanced cancer.

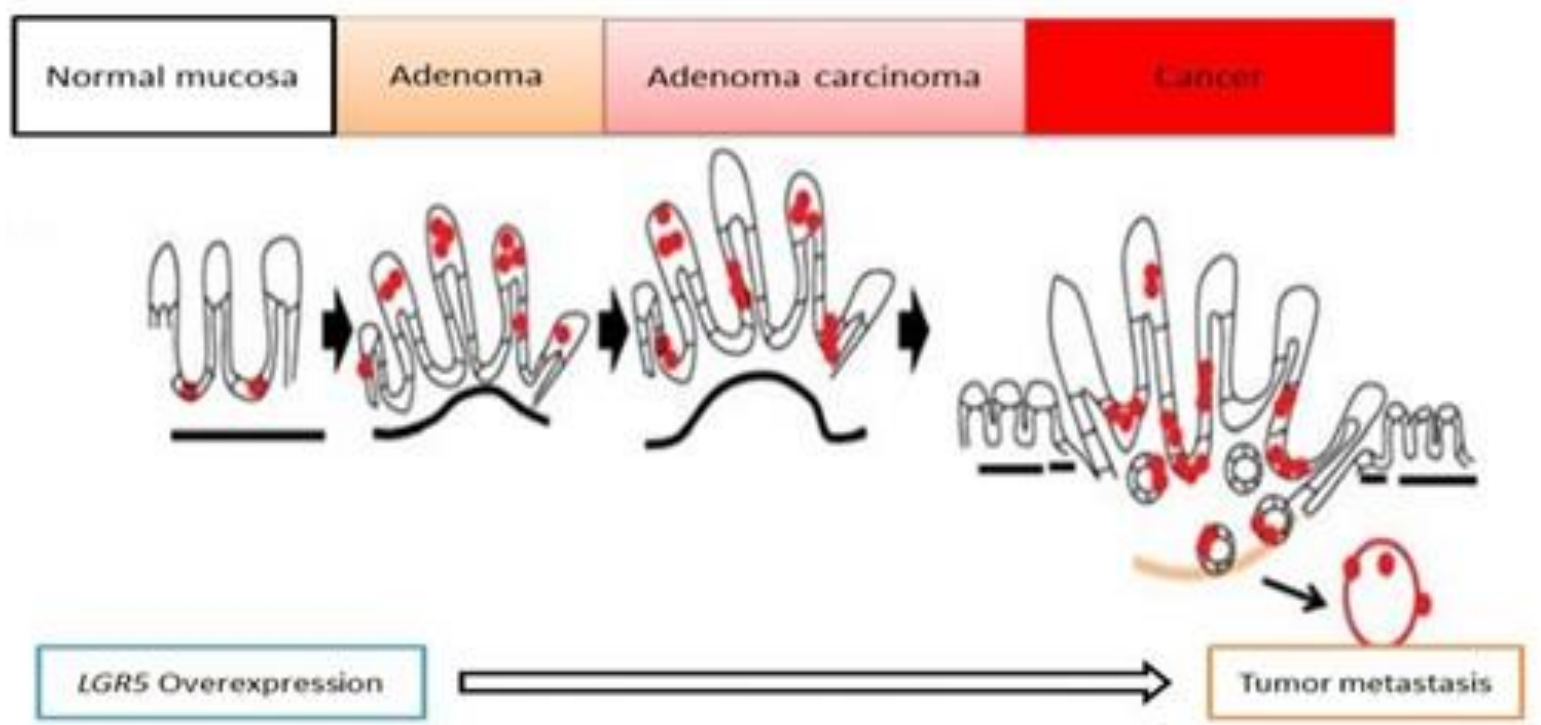

Figure 2. The effect of $L G R 5$ upregulation on colorectal carcinogenesis.

Although several investigations indicated the role of the LGR5 gene in CRC (Table 1), molecular mechanisms of LGR5 and CRC have been poorly understood. In this review, we discuss the oncogenic role of $L G R 5$ in CRC progression. 
Table1

Summary of Several Instigations about the Role of LGR5 Gene and Protein in CRC

\begin{tabular}{|c|c|c|c|}
\hline References & Samples & Method & Conclusion \\
\hline Shin et al. (2021) & Mouse model & Real-time PCR & $\begin{array}{l}\text { DDK2 knockdown increased LGR5 } \\
\text { expression and CRC [39]. }\end{array}$ \\
\hline Xu et al. (2020) & human CRC tissues & Western blot & $\begin{array}{l}\text { Overexpression of LGR5 protein was } \\
\text { correlated with advanced stage, cell } \\
\text { differentiation, depth of infiltration, poor } \\
\text { overall survival. Metastasis, vascular } \\
\text { invasion, liver metastasis, and LNM. LGR5 } \\
\text { was an independent risk factor [40]. }\end{array}$ \\
\hline Gzil et al. (2020) & human CRC tissues & $\begin{array}{l}\text { Immunohistochemical } \\
\text { staining }\end{array}$ & $\begin{array}{c}\text { LGR5 up-regulation increased lymph-node } \\
\text { metastases, vascular invasion, and poor } \\
\text { survival [50]. }\end{array}$ \\
\hline $\begin{array}{l}\text { Ihemelanda et al. } \\
\qquad(2019)\end{array}$ & $\begin{array}{l}\text { Paraffin-embedded tissue } \\
\text { blocks }\end{array}$ & Tissue microarray & $\begin{array}{l}\text { Overexpression of } L G R 5 \text { was an independent } \\
\text { biomarker for overall survival [41]. }\end{array}$ \\
\hline Jange et al. (2018) & $\begin{array}{l}\text { Paraffin-embedded tissue } \\
\text { blocks and cell line }\end{array}$ & $\begin{array}{l}\text { Immunohistochemistry, } \\
\text { tissue microarray, and Real- } \\
\text { time PCR }\end{array}$ & $\begin{array}{l}\text { Upregulation of } L G R 5 \text { was correlated with } \\
\text { adenoma-carcinoma transition [32]. }\end{array}$ \\
\hline Jang et al. (2016) & Human colonic polyps & $\begin{array}{l}\text { Reverse transcription- } \\
\text { polymerase chain reaction }\end{array}$ & $\begin{array}{l}\text { Overexpression of } L G R 5 \text { was related to a } \\
\text { precancerous lesion of CRC and tubular } \\
\text { adenoma [51]. }\end{array}$ \\
\hline $\begin{array}{l}\text { Szkandera et al. } \\
\qquad(2015)\end{array}$ & $\begin{array}{l}\text { Paraffin-embedded tissue } \\
\text { blocks }\end{array}$ & PCR & $\begin{array}{l}\text { The } L G R 5 \text { rs17109924 T>C wile-type } \\
\text { genotype was associated with } L G R 5 \\
\text { upregulation and increased resistance to 5- } \\
\text { FU-based chemotherapy [44]. }\end{array}$ \\
\hline Wang et al. (2015) & $\begin{array}{c}\text { Primary CRC tissues } \\
\text { from patients, mouse } \\
\text { model, human adenomas cells }\end{array}$ & Immunohistochemistry & $\begin{array}{l}\text { Up-regulation of LGR5 and CRC progression } \\
\text { [37] }\end{array}$ \\
\hline Lin et al. (2015) & $\begin{array}{l}\text { Human CRC, tissues, CRC } \\
\text { cell line }\end{array}$ & Real-time RT-PCR & $\begin{array}{l}\text { Reduction of proliferation, growth, migration, } \\
\text { and invasion using knock-downing of LGR5 } \\
{[52]}\end{array}$ \\
\hline He et al. (2014) & $\begin{array}{l}\text { Primary tumors } \\
\text { from CRC patients }\end{array}$ & Real-time RT-PCR & $\begin{array}{l}\text { The expression level of } L G R 5 \text { estimated a } \\
\text { poor prognosis [38]. }\end{array}$ \\
\hline Chen et al. (2014) & Meta-analysis & Meta-Analysis & $\begin{array}{l}\text { The expression level of LGR5 showed a poor } \\
\text { prognosis [53]. }\end{array}$ \\
\hline Choi et al. (2014) & Mice model & $\begin{array}{l}\text { Side-view confocal } \\
\text { endomicroscopy }\end{array}$ & $\begin{array}{c}\text { Upregulation of } L G R 5 \text { in tumors and } \\
\text { adenomas was observed and considered as a } \\
\text { prognostic marker for CRC [43]. }\end{array}$ \\
\hline $\begin{array}{l}\text { Al-Kharusi et al. } \\
\text { (2013) }\end{array}$ & Adenomas cell line & $\begin{array}{l}\text { Western blot, quantitative } \\
\text { real-time PCR }\end{array}$ & $\begin{array}{l}\text { Decrease in cell proliferation, growth, } \\
\text { migration, and invasion by knock-downing } \\
\text { LGR5 [54]. }\end{array}$ \\
\hline Hsu et al. (2013) & $\begin{array}{l}\text { Paraffin-embedded tissue } \\
\text { blocks }\end{array}$ & Immunohistochemistry & $\begin{array}{l}\text { Up-regulation of LGR5 expands cancerous } \\
\text { cells proliferation and chemotherapy } \\
\text { resistance [54]. }\end{array}$ \\
\hline Becker et al. (2008) & $\begin{array}{l}\text { Paraffin-embedded tissue } \\
\text { blocks }\end{array}$ & Immunostaining & $\begin{array}{c}\text { Upregulation of LGR5 in adenomas } \\
\text { compared with normal group imaging [55]. }\end{array}$ \\
\hline
\end{tabular}

\section{Methods}

In the current investigation, we obtained many articles published in English using electronic databases, including PubMed and Google Scholar, Scopus, and Web of Sciences. The following keywords were used in the search strategy: colorectal cancer, cancer stem cell, $L G R 5$, and adenoma-carcinoma sequence.

\section{Structure of LGR5}

LGR5 is a member of the G protein-coupled receptors (GPCRs) family with a large extracellular domain counting multiple leucine-rich repeats (LRRs). R-spondin proteins are the biological ligands of LGR5. The LGR5 is a member of GPCR class A receptor proteins that are located on chromosome 12q22 with 144kb longe [20]. LGR family proteins have 
been divided into three categories, including A, B, and C. LGR5 belongs to the B receptor group and has 13-18 LRR-containing domains and a linker area between the last LLR domain and the first transmembrane [21].

Furthermore, LGR5 is a member of the Wnt signaling pathway; co-stimulation of LGR5 ligand along with R-spondin 1 and Wnt-3a increased induction of LGR5 gene expression and initiation of related signaling pathways. LGR5 also cooperates with LRP6 and FZD5 via a clathrin-dependent pathway to form a ternary complex upon Wnt ligand binding. Although the LGR5 gene can promote different types of cancers via the regulation of Wnt and NOTCH signaling pathways, it can be specifically expressed in the small intestinal crypt and introduced as a potential marker for CRC [21, 22].

\section{The Role of LGR5 in Cancer Progression}

Identifying cancer biomarkers can provide relevant and effective ideas for developing new anti-cancer treatment strategies [12]. An abnormal increase in LGR5 may be one of the most common changes at the molecular level in some human cancers, leading to long-term enhancement of Wnt / $\beta$-catenin signaling [23]. LGR5-mediated suppression of Wnt / $\beta$ catenin signaling has also been reported in certain cancers such as B cell malignancies. To date, a therapy targeting the LGR5 signaling pathway in clinical approaches is not available. However, evidence suggests that the endogenous $L G R 5^{+}$cell population plays key roles in tumor onset, progression, and metastasis [24]. Thus, targeted therapeutic modulation of the $L G R 5^{+}$cancer cell population by targeting Wnt/ $\beta$-catenin signals through the targeted drug delivery system or genome modification may be promising for new anticancer therapies [25]. In addition, a combination of therapeutic drugs targeting both $L G R 5^{+}$and $L G R 5^{-}$cancer cells may receive more attention due to the plasticity of the cancer cells [13, 26]. Also, targeting more cancer cells using dual biomarkers may be much safer and more effective for anticancer treatment [27]. The role of this biomarker in the treatment of cancers in other tissues of the body is also being investigated, where it is found to be more effective in identifying gastrointestinal cancers. Available evidence suggests that high-grade serous ovarian carcinoma originates most often from stem cells in the fallopian tube epithelium, and the Wnt signaling pathway augmented by LGR5 supports tumor development and progression [28]. Additionally, $\mathrm{T}$ regulatory cells in the immune system modulation can increase the LGR5 expression in gastric cancer cells through the TGF- $\beta 1$ gene and signaling pathway. This pathway may include activation of the Wnt signaling, and the expression of this biomarker via TGF- $\beta$ gives a prognosis in gastric cancer [29]. Another study has reported that suppression of this marker is implicated in the treatment or prevention of breast cancer [30]. Also, LGR5 may serve as a future potential biomarker for patient risk stratification and metastasis in papillary thyroid cancer [31]. Therefore, identifying these biomarkers in the treatment of various cancers can greatly benefit.

\section{The Effect of $L G R 5$ in CRC}

Overexpression of the LGR5 gene in CRC patients was related to the canonical Wnt signaling activation and poor outcomes of patients $[10,32]$. Researchers indicated that $\beta$-catenin is induced by Wnt signaling activation, resulting in LGR5 upregulation and carcinogenesis. So, they suggested that LGR5 gene upregulation is an important factor in CRC progression [33, 
34]. LVI was found to be associated with malignant features, including inflammation, epithelial-mesenchymal (EMT), angiogenesis, and advanced stages [35]. Gzil et al. demonstrated that LGR5 gene expression was significantly linked to CRC patients with positive LVI and invasion; in addition, $L G R 5$ gene expression could be able to activate some downstream signaling $\mathrm{Wnt} / \beta$-catenin pathways, such as c-MYC, CDKN1A, and NOTCH [36].

Wang et al. reported that LGR5 overexpression was correlated with tumor size, malignant features, and Hepatocellular carcinoma progression [37]. Also, previous studies illustrated that the expression level of the LGR5 gene was a novel prognostic biomarker for CRC [10, $25,38]$.

Recently, Shin et al. have shown that knock out of $D D K 2 N$ reduced the expression level of the LGR5 gene and increased CRC progression in a mouse model. They suggested that the expression levels of LGR5 could be controlled with targeted therapy [39].

Results obtained from Xu et al. showed that upregulation of LGR5 protein in CRC tissue was linked to advanced stages, cellular differentiation, depth of infiltration, lymph nodes metastasis (LNM), vascular invasion, liver metastasis, and distant metastasis. In contrast, a significant correlation of decreased expression of LGR5 protein with better overall survival in patients with CRC was observed. Furthermore, they mentioned that LGR5 may be an independent risk factor for CRC prognosis [40].

In another study, Ihemelanda et al. revealed the prognostic role of $L G R 5$ as a potential biomarker for the detection of CRC [41]. Jang et al. identified a significant association of the LGR5 gene and protein with clinicopathological features, including older age, welldifferentiated tumors, and nuclear $\beta$-catenin expression. Furthermore, the overexpression level of LGR5 was found during the adenoma-carcinoma sequence [42].

Choi et al. reported LGR5 upregulation in colonic tumors and its association with malignancy risk of adenomas using side-view confocal endomicroscopy in mice model. Besides, they suggested LGR5 protein as a potential biomarker for the prognosis of colon cancer [43].

Szkandera et al. found that the LGR5 rs $17109924 \mathrm{~T}>\mathrm{C}$ wile-type genotype was correlated with LGR5 upregulation and enhanced resistance to 5-FU-based chemotherapy. Furthermore, they suggested the LGR5 rs $17109924 \mathrm{~T}>\mathrm{C}$ can be a prognostic marker for time recurrence in patients with colon cancer treated with 5-FU-based chemotherapy [44].

\section{LRG5 Targeted Therapy for CRC Treatment}

Although the structural feature of LGR5 is known, there are no approved LGR5 inhibitors. Junttila et al. utilized anti-LGR5-vc-MMAE antibody-drug conjugate (ADC) for targeted therapy of CRC, where LGR5-MMAE was capable of decreasing tumor size and growth in a mouse model [45]. Also, researchers used the LGR5-iCaspase9 knock-in organoids with cetuximab (anti-EGFR antibody) and oxaliplatin (platinum-based chemotherapeutic), where the potential of combined chemotherapy potentiates $L G R 5^{+} \mathrm{CSC}$ targeting for CRC cells [46]. The functional role of miR-100 as the LGR5 gene inhibitor was demonstrated by Zhou et al., where miR-100 was found to reduce LGR5 expression in colon cancer via joining 3untranslated regions [47]. Some new methods, such as CRISPR/Cas9 could be utilized for $L G R 5$ therapy investigations $[48,49]$. 


\section{Conclusions}

In summary, this review indicated that LGR5 gene upregulation is an independent prognostic biomarker for aggressive clinicopathological features in CRC. The high expression level of $L G R 5$ can lead normal tissue to adenoma-carcinoma sequence; in addition, its expression was associated with chemoresistance. LGR5 interacts with many signaling pathways like Wnt/ $\mathrm{B}$ catenin. An increasing body of evidence suggests an important role of LGR5 in CRC carcinogenesis. Moreover, finding the exact mechanisms of $L G R 5$ and its effect on CRC progression needs more investigations. Therefore, the utilization of new methods for LGR5 detection and targeted therapy might become novel research approaches for CRC treatment.

\section{References}

[1] Capp JP. Cancer stem cells: From historical roots to a new perspective. Journal of Oncology. 2019. doi: $10.1155 / 2019 / 5189232$

[2] Clarke MF. Clinical and therapeutic implications of cancer stem cells. N Engl J Med. 2019;380:2237-45.

[3] Henley SJ, Thomas CC, Lewis DR, Ward EM, Islami F, Wu M, et al. Annual report to the nation on the status of cancer, part II: Progress toward Healthy People 2020 objectives for 4 common cancers. Cancer. 2020;126:2250-66.

[4] Arnold M, Sierra MS, Laversanne M, Soerjomataram I, Jemal A, Bray F. Global patterns and trends in colorectal cancer incidence and mortality. Gut. 2017;66683-91.

[5] Yamagishi H, Kuroda H, Imai Y, Hiraishi H. Molecular pathogenesis of sporadic colorectal cancers. Chin J Cancer. 2016;35:1-8.

[6] Malki A, ElRuz RA, Gupta I, Allouch A, Vranic S, Al Moustafa A-E. Molecular mechanisms of colon cancer progression and metastasis: Recent insights and advancements. Int J Mol Sci. 2021;22:130.

[7] Peyravian N, Larki P, Gharib E, Nazemalhosseini-Mojarad E, Anaraki F, Young C, et al. The Application of Gene Expression Profiling in Predictions of Occult Lymph Node Metastasis in Colorectal Cancer Patients. Int J Mol Sci. 2018;6:27. doi: 10.3390/ijms22010130.

[8] Peyravian N, Nobili S, Pezeshkian Z, Olfatifar M, Moradi A, Baghaei K, et al. Increased expression of VANGL1 is predictive of Lymph Node Metastasis in Colorectal Cancer: Results from a 20-Gene expression signature. J Pers Med. 2021;11:126.

[9] Asadzadeh Aghdaei H, Pezeshkian Z, Abdollahpour-Alitappeh M, Nazemalhosseini Mojarad E, Zali MR. The role of Angiogenesis in Colorectal Polyps and cancer, a review. Mljgoums. 2018;12:1-6.

[10] Lin Y, Wu T, Yao Q, Zi S, Yang M, li J. LGR5 promotes the proliferation of colorectal cancer cells via the Wnt/?catenin signaling pathway. Oncology Letters. 2015;9:2859-63.

[11] Das PK, Islam F, Lam AK. The roles of cancer stem cells and therapy resistance in colorectal carcinoma. Cells. 2020;9:1392. doi: 10.3390/cells9061392

[12] Fumagalli A, Oost KC, Kester L, Morgner J, Bornes L, Bruens L, et al. Plasticity of LGR5-Negative Cancer Cells Drives Metastasis in Colorectal Cancer. Cell stem cell. 2020;26:569-78.

[13] Wang W, Wan L, Wu S, Yang J, Zhou Y, Liu F, et al. Mesenchymal marker and LGR5 expression levels in circulating tumor cells correlate with colorectal cancer prognosis. Cell Oncol. 2018;41:495-504.

[14] Kobayashi S, Yamada-Okabe H, Suzuki M, Natori O, Kato A, Matsubara K, et al. LGR5-positive colon cancer stem cells interconvert with drug-resistant LGR5-negative cells and are capable of tumor reconstitution. Stem cells. 2012;30:2631-44.

[15] Ruffner H, Sprunger J, Charlat O, Leighton-Davies J, Grosshans B, Salathe A, et al. R-Spondin potentiates Wnt/ $\beta$ catenin signaling through orphan receptors LGR4 and LGR5. PloS one. 2012;7:e40976. doi: 10.1371/journal.pone.0040976

[16] Hoffmeyer K, Raggioli A, Rudloff S, Anton R, Hierholzer A, Del Valle I, et al. Wnt/ $\beta$-catenin signaling regulates telomerase in stem cells and cancer cells. Science. 2012;336:1549-54.

[17] Puglisi M, Tesori V, Lattanzi W, Gasbarrini G, Gasbarrini A. Colon cancer stem cells: Controversies and perspectives. World J Gastroenterol. 2013;19:2997-3006. 
[18] Xu L, Lin W, Wen L, Li G. LGR5 in cancer biology: functional identification of LGR5 in cancer progression and potential opportunities for novel therapy. Stem Cell Research \& Therapy. 2019;10:219. doi: 10.1186/s13287-019$1288-8$

[19] de Lau W, Peng WC, Gros P, Clevers H. The R-spondin/LGR5/Rnf43 module: regulator of Wnt signal strength. Genes Dev. 2014;28:305-16.

[20] Kumar KK, Burgess AW, Gulbis JM. Structure and function of LGR5: an enigmatic G-protein coupled receptor marking stem cells. Protein Sci. 2014;23:551-65.

[21] Kumar KK, Burgess AW, Gulbis JM. Structure and function of LGR5: An enigmatic G-protein coupled receptor marking stem cells. Protein Sci . 2014;23:551-65.

[22] Schuijers J, Clevers H. Adult mammalian stem cells: the role of Wnt, LGR5 and R-spondins. EMBO J. 2012;31:268596.

[23] Hirsch D, Barker N, McNeil N, Hu Y, Camps J, McKinnon K, et al. LGR5 positivity defines stem-like cells in colorectal cancer. Carcinogenesis. 2014;35:849-58.

[24] Zhou X, Geng L, Wang D, Yi H, Talmon G, Wang J. R-Spondin1/LGR5 Activates TGF $\beta$ signaling and suppresses colon cancer Metastasis. Cancer Res . 2017;77:6589-602.

[25] Chen Q, Zhang X, Li W-M, Ji Y-Q, Cao H-Z, Zheng P. Prognostic value of LGR5 in colorectal cancer: a metaanalysis. PloS one. 2014;9:e107013. doi: 10.1371/journal.pone.0107013

[26] Walker F, Zhang H-H, Odorizzi A, Burgess A. LGR5 is a negative regulator of Tumourigenicity, Antagonizes Wnt signalling and regulates cell adhesion in colorectal cancer cell lines. PloS one. 2011;6:e22733. doi: 10.1371/journal.pone.0022733.

[27] Takahashi H, Ishii H, Nishida N, Takemasa I, Mizushima T, Ikeda M, et al. Significance of $L G R 5$ cancer stem cells in the colon and rectum. Ann Surg Oncol. 2010;18:1166-74.

[28] Schindler AJ, Watanabe A, Howell SB. LGR5 and LGR6 in stem cell biology and ovarian cancer. Oncotarget. 2018;9:1346-55.

[29] Bu Z, Zheng Z, Zhang L, Li Z, Sun Y, Dong B, et al. LGR5 is a promising biomarker for patients with stage I and II gastric cancer. Chin J Cancer. 2013;25(1):79-89.

[30] Yang L, Tang H, Kong Y, Xie X, Chen J, Song C, et al. LGR5 Promotes breast cancer progression and maintains stemlike cells through activation of Wnt/ $\beta$-Catenin signaling. Stem Cells. 2015;33:2913-24.

[31] Michelotti G, Jiang X, Sosa JA, Diehl AM, Henderson BB. LGR5 is associated with tumor aggressiveness in papillary thyroid cancer. Oncotarget. 2015;6:34549-60.

[32] Jang BG, Kim HS, Chang WY, Bae JM, Kim WH, Kang GH. Expression profile of LGR5 and its prognostic significance in colorectal cancer progression. Am J Pathol. 2018;188: 2236-50.

[33] Zheng Z, Yu H, Huang Q, Wu H, Fu Y, Shi J, et al. Heterogeneous expression of LGR5 as a risk factor for focal invasion and distant metastasis of colorectal carcinoma. Oncotarget. 2017;9:30025-30033.

[34] Krausova M, Korinek V. Wnt signaling in adult intestinal stem cells and cancer. Cell Signal. 2014;26:570-9.

[35] Yang D, Lai X, Xu F, Li Y, Jiang W, Ma D. Prognosis and clinical characteristics of colorectal cancer patients with KRAS gene mutation: a 5-year follow-up study. Int J Clin Exp Pathol. 2019;12:409-18.

[36] Gzil A, Zarębska I, Jaworski D, Antosik P, Durślewicz J, Maciejewska J, et al. The prognostic value of leucine-rich repeat-containing G-protein (LGR5) and its impact on clinicopathological features of colorectal cancer. J Cancer Res Clin Oncol. 2020;146:2547-2557.

[37] Wang Y, Jiang CQ, Fan LF. Correlation of Musashi-1, LGR5, and pEGFR expressions in human small intestinal adenocarcinomas. Tumour biology. Tumour Biol. 2015;36:6075-82.

38. He S, Zhou H, Zhu X, Hu S, Fei M, Wan D, et al. Expression of $L G R 5$, a marker of intestinal stem cells, in colorectal cancer and its clinicopathological significance. Biomed Pharmacother. 2014;68:507-13.

[39] Shin JH, Jeong J, Choi J, Lim J, Dinesh RK, Braverman J, et al. Dickkopf-2 regulates the stem cell marker LGR5 in colorectal cancer via HNF4 $\alpha 1$. iScience. 2021;24:102411. doi: 10.1016/j.isci.2021.102411

[40] Xu N, Gao K, Luo H, Wu Y, Shen B, Liu K. Correlation of LGR5 expression with clinicopathological features of colorectal cancer and its diagnostic and prognostic values. J BUON. 2021;26:87-92.

[41] Ihemelandu C, Naeem A, Parasido E, Berry D, Chaldekas K, Harris BT, et al. Clinicopathologic and prognostic significance of $L G R 5$, a cancer stem cell marker in patients with colorectal cancer. Colorectal Cancer. 2019;8:CRC11. doi: $10.2217 / \mathrm{crc}-2019-0009$ 
[42] Jang BG, Kim HS, Chang WY, Bae JM, Kim WH, Kang GH. Expression Profile of LGR5 and Its Prognostic Significance in Colorectal Cancer Progression. Am J Pathol. 2018;188:2236-50.

[43] Choi JW, Kim JK, Choi M, Kim YR, Yun SH. In vivo imaging of LGR5-positive cell populations using confocal laser endomicroscopy during early colon tumorigenesis. Endoscopy. 2014;46:1110-1116.

[44] Szkandera J, Herzog S, Pichler M, Stiegelbauer V, Stotz M, Schaberl-Moser R, et al. LGR5 rs17109924 is a predictive genetic biomarker for time to recurrence in patients with colon cancer treated with 5-fluorouracil-based adjuvant chemotherapy. Pharmacogenomics J. 2015;15:391-96.

[45] Junttila MR, Mao W, Wang X, Wang BE, Pham T, Flygare J, et al. Targeting LGR5+ cells with an antibody-drug conjugate for the treatment of colon cancer. Science translational medicine. 2015;7:314ra186. doi: 10.1126/scitranslmed.aac7433

[46] Shimokawa M, Ohta Y, Nishikori S, Matano M, Takano A, Fujii M, et al. Visualization and targeting of $L G R 5(+)$ human colon cancer stem cells. Nature. 2017;545:187-92.

[47] Zhou MK, Liu XJ, Zhao ZG, Cheng YM. MicroRNA-100 functions as a tumor suppressor by inhibiting LGR5 expression in colon cancer cells. Mol Med Rep. 2015;11: 2947-52.

[48] Peyravian N, Malekzadeh Kebria M, Kiani J, Brouki Milan P, Mozafari M. CRISPR-Associated (CAS) Effectors Delivery via Microfluidic Cell-Deformation Chip. Materials. 2021;14:3164. doi: 10.3390/ma14123164

[49] Cortina C, Turon G, Stork D, Hernando-Momblona X, Sevillano M, Aguilera M, et al. A genome editing approach to study cancer stem cells in human tumors. EMBO Mol Med. 2017;9:869-79.

[50] Gzil A, Zarębska I, Jaworski D, Antosik P, Durślewicz J, Maciejewska J, et al. The prognostic value of leucine-rich repeat-containing G-protein (LGR5) and its impact on clinicopathological features of colorectal cancer. J Cancer Res Clin Oncol. 2020;146:2547-57.

[51] Jang BG, Kim HS, Kim KJ, Rhee YY, Kim WH, Kang GH. Distribution of intestinal stem cell markers in colorectal precancerous lesions. Histopathology. 2016;68:567-77.

[52] Lin YU, Wu T, Yao Q, Zi S, Cui L, Yang M, et al. LGR5 promotes the proliferation of colorectal cancer cells via the Wnt/ $\beta$-catenin signaling pathway. Oncol Lett. 2015;9:2859-63.

[53] Chen Q, Zhang X, Li WM, Ji Y-Q, Cao HZ, Zheng P. Prognostic Value of LGR5 in Colorectal Cancer: A MetaAnalysis. PloS one. 2014;9:e107013. doi: 10.1371/journal.pone.0107013

[54] Al-Kharusi MR, Smartt HJ, Greenhough A, Collard TJ, Emery ED, Williams AC, et al. LGR5 promotes survival in human colorectal adenoma cells and is upregulated by PGE2: implications for targeting adenoma stem cells with NSAIDs. Carcinogenesis. 2013;34:1150-57.

[55] Becker L, Huang Q, Mashimo H. Immunostaining of LGR5, an intestinal stem cell marker, in normal and premalignant human gastrointestinal tissue. The Scientific World Journal. 2008;8:1168-76.

\section{Acknowledgements}

Not applicable.

\section{Disclosure Statement}

No potential conflict of interest was reported by the authors.

\section{Funding Acknowledgements}

Not applicable. 